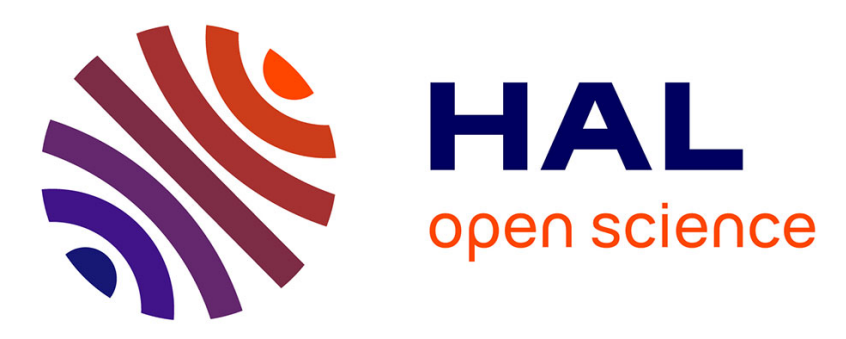

\title{
THE ENERGY TRANSFER PROCESS [MATH]
}

\author{
A. Pravilov, L. Smirnova, A. Vilesov
}

\section{To cite this version:}

A. Pravilov, L. Smirnova, A. Vilesov. THE ENERGy TRANSFER PROCESS [MATH]. Journal de Physique IV Proceedings, 1991, 01 (C7), pp.C7-592-C7-592. 10.1051/jp4:19917159 . jpa-00250835

\section{HAL Id: jpa-00250835 https://hal.science/jpa-00250835}

Submitted on 1 Jan 1991

HAL is a multi-disciplinary open access archive for the deposit and dissemination of scientific research documents, whether they are published or not. The documents may come from teaching and research institutions in France or abroad, or from public or private research centers.
L'archive ouverte pluridisciplinaire HAL, est destinée au dépôt et à la diffusion de documents scientifiques de niveau recherche, publiés ou non, émanant des établissements d'enseignement et de recherche français ou étrangers, des laboratoires publics ou privés. 
THE ENERGY TRANSFER PROCESS N $\left({ }^{4} \mathrm{~S}\right)+\mathrm{N}\left({ }^{4} \mathrm{~S}\right) \stackrel{(\mathrm{M})}{\longrightarrow} \mathrm{N}_{2} \stackrel{\mathrm{XeF}_{2}}{\longrightarrow} \mathrm{XeF}(\mathrm{B})+\mathrm{N}_{2}(\mathrm{X})+\mathrm{F}$

A.M. PRAVILOV, L.G. SMIRNOVA and A.F. VILESOV

Institute of Physics, Leningrad State University, Leningrad 198904, USSR

We have found out the energy transfer process from the excited nitrogen molecules formed in the nitrogen atoms recombination to the $X_{e} F_{2}$ molecules leading to the $\operatorname{XeF}(B)$ eximer formation:

$$
\begin{aligned}
N\left({ }^{4} \mathrm{~S}\right)+N\left({ }^{4} \mathrm{~S}\right) & \stackrel{(\mathrm{M})}{\rightarrow} \mathrm{N}_{2}^{*} \\
\mathrm{~N}_{2}{ }^{*}+\mathrm{XeF}_{2} & \rightarrow \mathrm{XeF}(\mathrm{B})+\mathrm{N}_{2}+\mathrm{F} \\
\mathrm{XeF}(\mathrm{B}) & \rightarrow \mathrm{Xe}+\mathrm{F}+\mathrm{h} \nu_{1}
\end{aligned}
$$

(here $N_{2}^{*}=N_{2}\left(A^{3} \Sigma_{u}^{+}, B^{3} \Pi_{g}, B^{3} 3 \Sigma_{u}^{-}, W^{3} \Delta_{u} ; v\right)$.

Preliminary studies have shown that: 1 . reaction (2) rate constant is close to gas-kinetic one; 2 . the chemiluminescence intensity is proportional to square of the nitrogen atoms concentrations and helium concentration. Therefore reaction

$$
\mathrm{N}\left({ }^{4} \mathrm{~S}\right)+\mathrm{N}\left({ }^{4} \mathrm{~S}\right) \stackrel{(\mathrm{He})}{\longrightarrow} \mathrm{N}_{2} \stackrel{\mathrm{XeF}_{2}}{\longrightarrow} \operatorname{XeF}(\mathrm{B})+\mathrm{N}_{2}(\mathrm{X})+\mathrm{F} \text {; }
$$

may be characterized by thermolecular constants $k_{4}=I_{\mathrm{XeCl}} /[\mathrm{N}]^{2}[\mathrm{He}]$ photon $\mathrm{cm}^{6} /$ particle ${ }^{3} \mathrm{~s}$.

Addition of xenon to helium increases the $k_{4}$ values, probably, due to energy transfer $\mathrm{N}_{2}{ }^{*} \longrightarrow X e^{*} \longrightarrow X e F$ process having higher than reaction (2) efficiency. After various type of calibrations it has been possible for us to estimate the $k_{4}$ values: $k_{4}>1.510^{-34} \mathrm{~cm}^{6} / \mathrm{s}\left(p_{\mathrm{He}}=4-12\right.$ Torr). $>$ $4.510^{-34} \mathrm{~cm}^{6} / \mathrm{s}\left(\mathrm{P}_{\mathrm{He}}=4.4\right.$ Torr, $\mathrm{P}_{\mathrm{Xe}}=0.5$ Torr $)$. Comparison of these rate constants with the reaction (1) and (5) ones

$$
\mathrm{N}\left({ }^{4} \mathrm{~S}\right)+\mathrm{N}\left({ }^{4} \mathrm{~S}\right) \stackrel{\mathrm{M}}{\longrightarrow} \mathrm{N}_{2}
$$

( $k_{1}=110^{-33} \mathrm{~cm}^{6} / \mathrm{s}, k_{5}=510^{-33} \mathrm{~cm}^{6} / \mathrm{s}$, see [1] and references in it) shows fairly high efficiency of the reactions (1-3). One can suppose that these processes are interesting enough for chemical XeF laser creation.

[1] A.M.Pravilov, L.G.Smirnova, A.F.Vilesov J.Photochem. and Photobiol.

A:Chem. (in press). 